\title{
The Role of Emotional Intelligence on Workforce Agility in the Workplace
}

\author{
Zare Zardeini Hosein ${ }^{1}$ \& Ahmad yousefi ${ }^{2}$ \\ ${ }^{1}$ Department of Management, Ferdowsi University of Mashhad, Mashhad, Iran \\ ${ }^{2}$ Department of Management, Allameh Tabataba'i University, Tehran, Iran \\ Correspondence: Zare Zardeini Hosein, Department of Management, School of Administrative \& Economic \\ Sciences, Ferdowsi University of Mashhad, Mashhad, Iran. E-mail: hzare622@gmail.com
}

Received: May 12, 2012

doi:10.5539/ijps.v4n3p48
Accepted: July 2, $2012 \quad$ Online Published: July 16, 2012

URL: http://dx.doi.org/10.5539/ijps.v4n3p48

\begin{abstract}
This study is investigating the relationship between emotional intelligence and agility of the workforce in order to determine how indicators of emotional intelligence facilitate the agility at the individual level. Statistical Population of this study includes managers, supervisors and staffs of food companies and the simple random sampling method is used. Data has been analyzed by using hierarchical regression statistical methods and comparing average. The survey results have showed that emotional intelligence factors have an impact on workforce agility. The results also have revealed that factors which are related to interpersonal competence (Self-awareness, self-control and self-motivation) have more effects on the agility than factors which are related to social competence (empathy and relation management) and have a greater role in workforce agility changes. Use of the results of this survey in the selection and training of human resources help to create appropriate environment for changing management and organizations movement to agility.
\end{abstract}

Keywords: emotional intelligence, agile manufacturing, agile workforce, agility, change

\section{Introduction}

Instability and continuous changes in the workplace have caused difficulties for organizations success and have threatened their survival. This situation has forced organizations to reconsider their goals and strategies and emphasize on quick response to market needs. Organizations' efforts in achieving these goals, have created and introduced one of the latest organizational concepts named Agile Manufacturing in recent years (Ganguly et al., 2009).

The Agile Manufacturing approaches of organizations tries to achieve maximum flexibility in order to make appropriate responses to changes in the product market and consumers' needs, and also make the organization to be known as a pioneer organization by innovating and creating new changes in the market. Organizations access to this flexibility needs agility in all aspects such as strategy, technology, infrastructure and human resources. Among these aspects, various studies have considered the effective adaptation of worker as the most important factor in agility. Dependence of Agile manufacturing efficiency to mental effort, skills, knowledge and attitude of people, and also its high investment in human resources have lead the agile workforce to be the determining factors in success of agile manufacturing system (Sherehiy et al., 2007).

Studies about agility have emphasized the operational and mechanical aspects of workforce agility. These studies have tried to consider the impact of reward and empowering on agility and they also have tried to increase the quick and effective adaptation of workforce to changes by designing flexible work stations and using advanced and multi task machinery (Kathuria, and Partovi, 1999; Oyen et al., 2001; Hopp et al., 2004; Sumukadas and Sawhney, 2004; Pinker et al., 2010). However, these factors have important role in workforce agility, but in these studies, inherent ability of people such as psychological features, which have important role in human performance, changes management and organizational development have been refused.

Emotional intelligence is one of the psychological features that have been considered in this study. Since emotional intelligence is an important factor in the efficiency and effectiveness of the workforce, recognizing and using the effects of emotional intelligence can help to agile manufacturing systems (Nikolaou and Tsaousis, 2005). Moreover, the change and the instability of agile manufacturing system increase sentimental tensions and 
the inability of the workforce in decreasing and managing these tensions, can make unpleasant effects on their agility (Vakola et al., 2004). Recognition and use of Emotional abilities effects can help the agility of organizations and prepare a competitive situation for them. Therefore, with a different regard to workforce agility and considering relationship between Emotional intelligence standards and workforce agility, this research is trying to reveal how standards of Emotional intelligence can facilitate agility of organizations at the individual level.

\subsection{Agile Manufacturing}

The concept of agile manufacturing has been created and entered to the production literature by a group of researchers from Laccoa organization and Lehigh University in order to represent important factors and aspects of manufacturing and also the importance of the environmental changes role in organizations' success.

After agile manufacturing concept has been represented, lots of researchers have attempted to offer general definition of agility of organization and different definitions entered to literature of production. Goldman (1995), defines the agility in production as the ability of beneficial activity in a competitive environment with continuous and sudden changes in customer's requests and preferences. In Gunasekaran's opinion (1998), an agile organization is the one, which can react to sudden and unexpected changes efficiently. Yusuf and partners (1999), define the agility as an ability of obtaining competitive factors (speed, inflexion, innovation, productivity, quality and profitability) by incorporating resources and broadly identifying the environment in order to represent favorable production to customers in competitive market with rapid changes. Menor and partners (2001), define producing qualified product, cost efficiency and creating flexible structure that can reply to inside and outside changes suitably as the bases of organization agility. Ashrafi and his partners (2005), explain the organization agility as an ability of feeling environmental changes and efficient and effective reply to this change. Different definitions offered for agility, represent that the concept of agility is mostly defined as organization's ability to identify environmental changes and rapid reply to customers and beneficiaries by incorporating of resources, process and strategy (Zhang, 2011).

Studies about agility mostly include researches that concentrate on using agility providers and offering a frame to run agile manufacturing system. To determine the most important elements and agility providers some of these frames are being investigated.

In Goldman and his partner's opinion (1990) four strategic dimensions including customer, structure, communications, human and physical resources are important in order to get the ability of agility. According to their opinion, organizations should pay special attention to customers' wants and needs and also their received value of products. In addition, organizations cooperation and communication with other companies in representing products to market and innovation and flexible organization structure help the organization in its agility. In Goldman and his partner's opinion, ability of organization in responding to changes is possible when organization's physical and human resources are organized suitably and individuals motivation and creativity are noticed.

Meredith and Francis (2000) divide agility providers into four categories including process, guideline, communications and human resources. In their point of view these four dimensions are connected to each other, all of them would be necessary to reach agility, and if one of them is neglected, organization agility will be weakened.

According to Jackson and Johansson opinion (2003), ability of changing the product, coordinating organization's units, coordinating and collaborating organization with customers and suppliers and having skills are the methods and tools required to modify those things, which are important in organization agility for the organization. They believed competent persons and knowledge are the basic of all the actions to reach agility and individuals' learning, creativity and entrepreneurship can suitably provide changes for organizations.

The most comprehensive and the most famous presented framework in agility literature is the model of Sharifi and his partners (2001). In this model, four aspects of agility include agility stimulants, strategic abilities, agility abilities and agility providers have been studied. The agility stimulants are the features of organization external environment, which cause the environmental uncertainty and force the organization to make changes and adapt with environment. The strategic abilities include quick adaption, responding and flexibility, which have been represented as the most important features for an agile organization. The agility providers are strategies, technologies, innovation and human resources of organization, which provide the base of organization agility by affrication and good management.

Reviewing of these presents frameworks in agility shows that the agile workforce are an important element in 
achieving the internal agile manufacturing system of organization, and cooperation and collaboration of human resources is the key of agile organization success. The special attention to human resources of organization, Recruitment of competent staff and efforts in increasing their abilities and talents are the most important factors in organizational changes and they can increase the agile organization success.

\subsection{Agile Workforce}

Agility as a word means a quick and simple method movement (Ganguly et al., 2009) and the agility of workforce is the flexible, quick and efficient agility of workforce in a variable environment (Forsythe, 1997). Agile workforce is the most part of an organization in achieving the agile organization and inattention to this factor causes the weakness of organization agility. Cooperation, allegiance and capability of individuals are the base of an organization and use of skills, knowledge, acuteness, experience and intelligence of them for having the organizational capacity are key and important challenges in achieving organizational agility (Meredith and Francis, 2000).

Agile workforce help the organization use the flexible technology efficiently and provide a situation for changes in technology and methods. Agile workforce also help the organization act competitive in costs, quality, and the time of delivering and production diversity aspects and provides situation for better services to customers and frugality in organization (Plonka, 1997).

In the opinion of Hopp and Van (2004), the agile workforce can affect on four strategic purpose includes costs, time, quality and diversity and can help the organization in achieving agility. The Agility of workforce decreases the costs in three ways. First, Agile personnel have high efficiency because of their high flexibility and can do more activities in less time and they can reduce costs. Second, Increase in organization flexibility as a result of agile personnel decrease the investment in inventory and reduce the manufacturing costs. Finally, the cooperation of agile personnel makes the synergy in organization and duties will be done with higher quality and less costs. The Agility leads the personnel to do their duties faster and decrease lost time and production cycle. Decrease in time and production cycle deviations give the organization more time and provide situations for more secure delivery of products. The agility of personnel leads the internal quality to be better (decrease in loses and redoing) and external quality (providing the wants and needs of customers) and help the organization in competition. Personnel agility increase the flexibility in production and help the organization include a wider range of products diversity and represent them to customers. A Professional and multi task personnel makes them be able to displace and leads the organization to increase its diversity of production system (Hopp and Van 2004).

Having special features and abilities is necessary for workforce agility. Last studies in the literature represent different features and abilities of agile workforce. Positive attitude of Learning and empowering, the ability to creative solving of problem, positive attitude to organizational changes, giving creative comments and correct performance of the new responsibilities, are qualities which agile individuals have them, based on Plonka (1997) opinion. Gunasekaran (1999) thinks that active workforce in agile manufacturing system must have Skills related to information technology, efficient participation in team works, and the capability to work with modern technologies, and also know the techniques of negotiation and have the ability of performing different duties inside the organization.

In Dyer and Shafer (2003) opinion, representing three kinds of behavior include proactive behavior, adaptive behavior and production behavior by personnel can help the organization agility. In proactive behavior, people try to have an effective role in organizational success by using opportunities, new events and their creativity. Adaptive behavior needs to perform different roles in the organization. In adaptive behavior, people do different tasks and cooperate with internal parts and projects of organization. In production, behavior people learn new competences and abilities and train these competences to their colleagues by representing knowledge and information.

Griffin and Hesketh (2003) have presented an adaptability framework in work environment, which includes three kind of behavior: proactive, Reactive and Tolerant behavior. In their opinion, in individual proactive behavior, people make a positive effect on changed environment and it includes the behaviors such as creativity in solving the problems, overcoming the stress and adapting with crisis. In Reactive behavior, people change themselves to have better adaption with environment and it includes the behavior such as efforts for learning, physical adaptability, cultural adaptability and coordination with colleagues. In Tolerant behavior, the person tries to overcome the uncertainty, and decrease their stress and anxiety.

Sherehiy and his partners (2007) have considered the agile workforce features and have reviewed the conducted studies in this area. They based on the models of Griffin and Hesketh (2003) and Dyer and Shafer (2003), 
identified the most important attributes of agile workforce. Participation in organizational changes; personal creativity and innovation; adaption with people who have different professions and jobs; adaption with people who have different cultures; positive attitude to change; positive attitude to new technologies and comments; dealing with unpredictable situations; flexibility and dealing with stresses are the features that Sherehiy and his partners thinks that agile workforce have them.

\subsection{Emotional Intelligence}

Salovey and Mayer (1990) used emotional intelligence as a social intelligence with a different meaning from mental intelligence for the first time. Based on the Salovey and Mayer definition emotional intelligence is a kind of social intelligence, which enables people to examine the emotion and use the results for conducting thoughts and deeds. In 1997, Mayer and salovey have represented their emotional intelligence by revising in this definition. In this model, emotional intelligence was defined as the individualist ability in correct perception and evaluation of emotions, ability to facilitate thoughts by emotions and ability to adjust emotion for enhancement of emotional as well as mental growth (Mayer and salovey, 1997).

Another intelligence model was proposed by Bar-on (1997). Bar-on has defined emotional intelligence as a collection of competence and skills, which influences the success of a person under environmental pressures. Bar-on has distinguished between five different areas: interpersonal, intrapersonal, flexibility, managing stresses and overall mood. In each of these areas, there are specific skills, which Bar-on has considered them as emotional intelligence.

Although the concept of emotional intelligence was into literature by Mayer and salovey, but its fame is because of the Goleman efforts. Goleman (1998) represented his theory inspired by results of Mayer and salovey and he used his theory in working environment. Based on Goleman definition, emotional intelligence is the capacity to recognize our own feelings and those of others, for motivating ourselves, and managing emotions well in us and in our relationships. Goleman has proposed a model of emotional intelligence, which includes five domains of self-awareness, self- control, self- motivation, empathy and managing relations. In this category, Goleman relates three first parts of emotional intelligence to the internal competences and relates two next parts (Empathy \& relation management) to the intrapersonal skills (Goleman, 2000).

The main difference between the Goleman theory \& the other theories of Emotional intelligence is that Goleman based his model on the functional theories and his theory is provided for working environment. Therefore, this model has this application to be used in the working environment \& make it possible to predict the organizational efficiency and get the organizational competences.

In the last years, a lot of attention has been paid to Emotional intelligence as an effective fact on the organizational behaviors. And a different studies has been focused on the role of Emotional intelligence in organization \& how the Emotional intelligence can predict the behaviors which is related to work such as efficiency, stress management, attitudes to changes, job success, conflict management \& the leading power .

\subsection{Research's Hypothesis}

The importance \& role of the Emotional intelligence in the working environment is undeniable. In the Goleman's idea, the importance of Emotional intelligence in the people's success in the working environment is higher than the ordinary intelligence so that $80 \%$ of people's success is depended on that.

Researches show that people with high emotional abilities has a more effective operation (Thilam and Kirby 2002), has successful way of working (Weisinger, 1998) and face to less job insecurity feelings (Jordan et al., 2002). People with high Emotional intelligence match better with organizational events and they are more successful in adaptability with the organizational changes (Insead, 1999). Also these people have suitable attitudes to organizational changes (Vakola et al., 2003) \& they have more adequate operation in facing to the organizational conflict \& stress (Nikolaou and Tsaousis 2005).

In the Fiol and O'Connor (2002) ideas, the emotional ability is the base of Human's tolerance \& adaptability with the sudden changes. According to the Mayer and salovey's idea (1990) the Emotional intelligence makes the flexible programming, easy, improve the decision making process and facilitate the people's creativity and help people do their challenging and variable duties. Huy (1990) says that the Emotional intelligence is a very important fact in facing rapid changes and it is a key factor which determines the success or failure in organizational changes programs. Gabel and his partners (2005) determine the Emotional intelligence as an important fact in facing to culture, procedure and new policies and they believe that the high Emotional intelligence helps people in new operations and provide the careers needs. George and Jones (2001) say that adequate emotional reactions, recognition, and perception of emotion can create the necessary condition for 
facing appropriately to organizational changes. According to the Mossholder and his partner's (2000) theory, emotions have a very important role in the organizational changes and creating a positive situation in the organization to help the workforce to understand the emotions and regulate the emotional turmoil, and adapt with changes.

Although the emotional intelligence has not been studied in literature until now, but it can be inferred that the difference in emotional intelligence of individuals can lead to the differences in agility which shows the ability of flexible, quick and efficient movement of individuals in variable environment of organization. Therefore, in this study the assumption of the relation between the factors of emotional intelligence (self-awareness, self-control, self-motivation, empathy and relations management) and workforce agility has been examined.

Goleman determines the self-awareness as the base of the other elements in Emotional intelligence and defines it as the clear perception of the emotion. Feelings, weaknesses and strengths, needs and tastes. People who have higher levels of self-awareness have higher abilities and self esteem because they know their abilities. The people with self-awareness have more abilities in controlling and managing the events, they are accurate in their jobs. Their hopes are not unrealistic. In addition, they accept the responsibilities which are in their power. These people are honest with themselves and others and they know the effect of their emotion on themselves and others. they refuse violence and unfair critical. Because of All features, it has been supposed in this research that higher Self-awareness leads to more agility inside the organization (Goleman, 2001; Sunindijo et al., 2007).

\section{$\boldsymbol{H}_{1}$ : self-awareness has a positive impact on workforce agility}

Self-control means choosing the manner of expressing emotions, which can simplify the flow of thinking. Persons with the high self-control ability can control their negative emotions in hard and oppressive condition and they are able to regulate and modulate their negative emotions like disappointment anxiety and angriness. These persons face with fewer problems in their life and if any problem happens, they can return from that problematic and oppressive condition to good condition quickly. Self-control also helps people present rational decisions and judgments and makes them be able to endure with ambiguities and uncertainty. According to these features in this study, it has been supposed that more self-control leads to more agility inside the organization (Goleman, 2001; Bar-on, 1997).

\section{$\boldsymbol{H}_{2}$ : self-control has a positive impact on agility of workforce}

Self-motivation means the attention to values and interests in the side of access to individual goals and using them to improve the function and depositing the problems. The Self-motivated persons are more efficient in doing their tasks and they are hopeful and optimist though disappointment exists. They are result oriented and there are a lot of motivation in them to achieve the goals and standardizes. For this reason, it has supposed in this research that high Self-motivation leads to more agility in inside the organization (Goleman, 1998 , 2001; Jordan et al., 2002).

\section{$\boldsymbol{H}_{3}$ : Self-motivation has a positive influence on agility of workforce}

In Golman opinion empathy means understanding the emotions of others and using appropriate behavior and doing their interests reaction. Empathy leads person to be familiar with others behavior which show their needs and wants and understand them. The sympathetic persons have responsibility to others and respect their feelings. They show their interest in communications and activities. These people respect others opinions and they do not refuse them in their activities. According to these features, it has been supposed in this research that Sympathetic people inside the organization have more agility (Goleman, 1995, 1998; ; Sunindijo et al., 2007).

\section{$\boldsymbol{H}_{4}$ : Empathy has a positive influence on agility of workforce}

Social skill means ability of having influence on others emotions. Social skill is a necessary ability for communicating with others. These people can have widespread communicate and they can solve problems and conflict with others. Social skill gives this ability to person to reinforce other's abilities with feedbacks and guidance, encourages, and motivates others. People with social skill are not inactive in variable environment and they have ability to invent and manage new methods. These people understand the significance of cooperation and coordination in working environment and they are active in-group works. According to these features in this research, it has been supposed that high social skill leads to more agility inside the organization (Goleman, 1995,1998; Klem and Schlechter, 2008).

\section{$\boldsymbol{H}_{5}$ : social skill has a positive influence on agility of workforce}

Also in this research, it has been tried to compare the influence of interpersonal factors with intrapersonal factors of emotional intelligence. The interpersonal competences have more important role in of emotional intelligence 
effect on social people life. Management literature gives lots of attention to this intelligence. These competences help individuals to perform better in compare with the intrapersonal competences have and have higher importance (Kunnanatt, 2008). In the opinion of salovey and collaborators, (2000) recognition and management of emotion are the most important features of emotional intelligence that can determine the emotional ability of people.

According to these discussions in this research, we assume that the interpersonal competences which shows the ability of person in understanding and managing emotions and feelings, have more effects on agility comparing with intrapersonal competences which shows the ability of communications and interactions with others.

$\boldsymbol{H}_{6}$ : Interpersonal competences like self-awareness, self-motivation and self-control explain the changes in workforce agility more than intrapersonal competences

\section{Personal Variables}

There have not been any researches in personal and agility variables until now. In this study, we are trying to consider the impacts of job record, organizational position and education level on agility and control them in order to increase the funding.

Sumukadas and Sawhney (2004) have revealed that high awareness and training of staffs have a positive effect on agility. Iverson (1996) in his studies has proved the relation between job record and having positive feelings about organizational changes. Kathuria and Partovi (1999) has concluded that experienced and educated managers insist on flexibility more and they try to make diversity in their products, adapt the product to consumers ' needs, and make quick changes. Cordery and partners (1993) in their survey have revealed that there's a positive relationship between educational level of staffs and accepting changes. Vakola and partners (2003) have also revealed that there is a positive relationship between educational levels and positive feelings of staffs about organizational changes and their corporation with organizational changes. Therefore, in this study it has assumed that:

$\boldsymbol{H}_{7}$ : There is a positive relation between job record and people agility.

$\boldsymbol{H}_{8}$ : There is a positive relation between educational level and people agility.

Positions of people in high levels of organization lead them to connect with organizational problems and be more motivated. Being in high levels of organization gives people more information about organization and environment and understands the necessity of organization's adaptability and changes. Staffs of high levels of organization may also more participate in editing organization's plans. Consequently, they may understand the goals and expected results of organization's plan and within these plans, they would try more (Sumukadas and Sawhney, 2004). Thus, in this study we assume that the staffs of high levels of organization are more agile and they try to cause changes and lead the organization to agility.

$\boldsymbol{H}_{9}$ : There is a significant difference between agility grades of staffs of different organizational positions. (Staff of high-level positions got better grade in agility)

\section{Research Method}

This survey has been occurred in food companies of east Iran .Many successful companies work in this area. The statistical population of this research is managers, supervisors and administrative staffs of firms which have diversity in their productions and their staffs are more than 50 persons. The sample Size has been obtained from average distance estimation method and this equation:

$$
n=\frac{\frac{\alpha}{2}^{2} \sigma_{x}^{2}}{\varepsilon^{2}}
$$

In order to estimate the standard deviation a primary sample with 30 members has been used and the standard deviation has been calculated which equaled to 0.147 . Confidence level for this survey is $95 \%$ and the error level is $5 \%$.

A 225 members sample has been selected by random sampling from 22 firms .In order to collect the questionnaire the researches referred to the firms and the questionnaire have been filled. Researches visited the firms and distribute and collect the questionnaire .500 questionnaires have been distributed and the response rate has been obtained as $56 \%$.

In this research the statistical software, SPSS, has been used for data analysis and Pearson correlation coefficient, hierarchical regression and comparing average have been used for testing research hypothesis. 
For measuring the emotional intelligence, the questionnaire designed by Weisinger (1998) has been used in this research. This questionnaire has an appropriate validity and its stability has been proved in Yost and partners study (2001), Yost and Tucker study (2000), and Myers and Tucker (2005). This questionnaire includes five factors: self-awareness, self-control, self-motivation, Empathy and relation management based on Likert 5 scale and consist 25 questions.

The Weisinger questionnaire was used for two reasons. First, in widespread studies with high number of samples, use of more valid and shorter questionnaire is more beneficial (Carmeli, 2003). And Second, this study was occurred in organizational environment and this questionnaire is appropriate for this goal (Weisinger, 1998).

However, different features of agile workforce have been represented in agility literature, but few numbers of studies has measured the agility of workforce. In order to design the workforce agility measuring scale, the features represented by Sherehiy et al. (2007) have been chosen and the questionnaire has been designed base of them. The studied by Frese et al. (1997), Musteen et al. (2006) and Pulakos et al. (2002) help designing the questionnaire. The scale used in this questionnaire, is Likert 5 scale and includes 25 questions.

The validity of questionnaire was evaluated based on Cronbach's alpha coefficient. The alpha for emotional intelligence and agility are $82 \%$ and $80 \%$ that highlight the validity of questionnaire.

In the head of the questionnaire, the questions about personal variables are placed. Questions about educational levels and organizational position are multi option and the questions about job record are single option. Options of educational level are: Diploma (1), Associated Diploma (2), Bachelor of Science (3) and Master of Science (4). Options of organizational position are administrative personnel (1), supervisor (2) and manager (3). The respondents have determined their job records with year.

\section{Results}

In order to examine the relationship between variables, correlation analysis was performed. Correlation analysis results are shown in Table 1. This table shows all the factors of emotional intelligence (self-awareness, $\mathrm{p} \leq .01, \mathrm{r}$ $=.534$; self -motivation, $\mathrm{p} \leq .01, \mathrm{r}=.652$; self-control, $\mathrm{p} \leq .01, \mathrm{r}=.541$; empathy, $\mathrm{p} \leq .01, \mathrm{r}=.609$; Social skills, $\mathrm{p} \leq .01$, $\mathrm{r}=.592$ ) have a positive relation with workforce agility and the first 5 assumptions are consistent with the results of research. In addition, the correlation analysis shows that the education level of employees linked with their agility but denies the relationship between job record and workforce agility .so the assumption $\mathrm{H}_{7}$ is denied and the assumption $\mathrm{H}_{8}$ is accepted.

Table 1. Correlation analysis results

\begin{tabular}{llllllllll}
\hline variable & $\min$ & $\mathrm{SD}$ & 1 & 2 & 3 & 4 & 5 & 6 & 7 \\
\hline 1. job record & 9.69 & 7.95 & & & & & & & \\
2. educational level & 2.23 & .99 & & & & & & & \\
3. self-awareness & 21 & 2.46 & -.038 & .11 & 1 & & & & \\
4. self-control & 18.9 & 3.32 & .017 & -.005 & .415 & 1 & & & \\
5. self -motivation & 19.9 & 3.02 & -.011 & .086 & .521 & .593 & 1 & & \\
6. empathy & 19.1 & 2.94 & .028 & .044 & .371 & .476 & .531 & 1 & \\
7. Social skills & 20.9 & 2.41 & .044 & -.023 & .463 & .301 & .488 & .467 & 1 \\
8. agility & 85.23 & 9.5 & -.021 & $.173^{*}$ & $.534^{* *}$ & $.541^{* *}$ & $.652^{* *}$ & $.609^{* *}$ & $.592^{* *}$ \\
$\mathrm{P}^{*} \leq 0.05, \mathrm{p}^{* *} \leq 0.01$ & & & & & & & & & \\
\hline
\end{tabular}

Mean contrast test has been done in three levels In order to examine whether the agility grade of people in managerial, supervisory, and administrative is different or not. The test results are shown in Table 2. The significant test in mean difference of agility variable in management and supervisory and administrative levels showed that there are differences between the grade of these three levels $(\mathrm{sig}=.035)$. Therefore, the assumption, which states that grades of agility are identical, would be refused. This test also shows that with the possibility of $99 \%$, there is a linear relationship between agility and organizational position ( $\mathrm{sig}=.01$ ) so the assumption $\mathrm{H}_{9}$ is accepted.

In order to check that which of the emotional intelligent factors can predict the changes of the grades of 
workforce agility, the hierarchical Regression has been done. Because the results of correlation analysis and the mean comparison test has proved the relation between educational level and organizational position with the agility of workforce, in this test educational level and organizational position have been used as the control variable. Therefore, at the first step of the Regression test these two variables have entered to the model. After that in order to check assumption $\mathrm{H}_{6}$, the interpersonal factors have been used and influences of them have been controlled. Finally, the intrapersonal factors have been entered into the model. The results of the Regression analysis are shown in the table 3 .

Table 3 shows that all of the emotional intelligent factors predict the changes of the agility and have positive effect on the agility. Therefore, the results of the Regression analysis underscored $\mathrm{H}_{1}, \mathrm{H}_{2}, \mathrm{H}_{3}, \mathrm{H}_{4}$ and $\mathrm{H}_{5}$ assumptions. The equation of the hierarchical Regression analysis that we can compute the score of the agility of work power using the scores of emotional intelligent components via it is the following.

$$
\mathrm{Y}=13.3+.53 \times 1+.44 \times 2+.716 \times 3+.733 \times 4+1.038 \times 5
$$

In which Self-awareness X1, self-control X2, self-motivation X3, Empathy X4 and X5 is social skill.

Table 2. Result of mean contrast test

\begin{tabular}{|c|c|c|c|c|c|c|c|c|c|}
\hline & & & & & $\begin{array}{l}\text { Sum of } \\
\text { Squares }\end{array}$ & $\mathrm{df}$ & $\begin{array}{l}\text { Mean } \\
\text { Square }\end{array}$ & $\mathrm{F}$ & sign \\
\hline Agility & $\&$ & Between & (Combined) & & 602.107 & 2 & 301.054 & 3.403 & .035 \\
\hline \multirow[t]{4}{*}{ Position } & & Groups & Linearity & & 593.649 & 1 & 593.649 & 6.710 & .010 \\
\hline & & & $\begin{array}{l}\text { Deviation } \\
\text { linearity }\end{array}$ & from & 8.458 & 1 & 8.458 & .096 & .757 \\
\hline & & Within Groups & & & 19287.12 & 223 & 88.473 & & \\
\hline & & Total & & & 19889.23 & 225 & & & \\
\hline
\end{tabular}

Finally, the comparison of model determining coefficient changes in entrance of interpersonal and intrapersonal competence (stage $2 \& 3$ ) shows that changes of model determining coefficient would be more by entrance of interpersonal competence and confirms the assumption $\mathrm{H} 6$ results $(\Delta \mathrm{R} 2=.483>\Delta \mathrm{R} 2=.103$ and $\mathrm{Sig}=.0)$.

Table 3. Result of hierarchical Regression

\begin{tabular}{|c|c|c|c|c|c|c|c|c|c|}
\hline \multirow[t]{2}{*}{ stage } & \multirow[t]{2}{*}{ Variable entered } & \multirow[t]{2}{*}{ Model variables } & \multicolumn{2}{|l|}{$\alpha$} & \multirow[t]{2}{*}{$\mathrm{R}^{2}$} & \multirow{2}{*}{$\begin{array}{c}\beta \\
\text { amount }\end{array}$} & \multicolumn{3}{|c|}{$\overline{\Delta \mathrm{R}^{2}}$} \\
\hline & & & amount & sig & & & $\operatorname{sig}$ & amount & $\operatorname{sig}$ \\
\hline \multirow[t]{2}{*}{1} & $\begin{array}{l}\text { Organizational } \\
\text { position }\end{array}$ & $\begin{array}{l}\text { Organizational } \\
\text { position }\end{array}$ & 1.75 & .047 & .32 & 81.06 & .00 & .32 & .029 \\
\hline & $\begin{array}{l}\text { Educational } \\
\text { level }\end{array}$ & Education & .504 & .48 & & & & & \\
\hline \multirow[t]{5}{*}{2} & $\begin{array}{l}\text { self-awareness } \\
\text { Self-control }\end{array}$ & $\begin{array}{l}\text { Organizational } \\
\text { position }\end{array}$ & 1.3 & .04 & .515 & 27.78 & .00 & .483 & .00 \\
\hline & Self-motivation & Education & 9.54 & .85 & & & & & \\
\hline & & self-awareness & .93 & .00 & & & & & \\
\hline & & Self-control & .55 & .001 & & & & & \\
\hline & & Self-motivation & 1.26 & .00 & & & & & \\
\hline \multirow[t]{7}{*}{3} & $\begin{array}{l}\text { empathy } \\
\text { social skill }\end{array}$ & $\begin{array}{l}\text { Organizational } \\
\text { position }\end{array}$ & .79 & .16 & .618 & 13.3 & .002 & .103 & .00 \\
\hline & & Education & .49 & .29 & & & & & \\
\hline & & self-awareness & .53 & .01 & & & & & \\
\hline & & Self-control & .44 & .005 & & & & & \\
\hline & & Self-motivation & .718 & .00 & & & & & \\
\hline & & empathy & .733 & .00 & & & & & \\
\hline & & social skill & 1.038 & .00 & & & & & \\
\hline
\end{tabular}

\section{Argument and Discussion}

In this research, the relationship between workforce agility and emotional intelligence factors has been 
considered. The result of the research revealed some important elements. First, the emotional intelligence interpersonal and intrapersonal features have a positive impact on agility. Secondly the interpersonal features of emotional intelligence, explains the agility changes more than intrapersonal features. Finally higher level of organizational position and education lead to higher agility.

There has not been any study about the relationship between education and agility until now. But there are some investigations in the literature of changing management which is compatible with the conclusion of this research that accept the relationship. Cordery and his partners (1993) have shown that there is a positive relationship between the education of personnel and accepting organizational changes, and express that personnel with higher level of education have more opportunities for learning and applying the skills, and so they are more able to response the new necessities and adapt with the challenges of changes. This result adapts with the sequences of Kathuria and Partovi (1999) who demonstrated relationship between education of managers and they attempt for achievement of quick changes, increasing production variety and increasing flexibility. In addition, this result adapts with Iverson (1996) issues. He showed that training the personnel causes increasing their flexibility, conformity and impress their partnership in organization changes.

This research showed that situation in organization is a determining factor in agility. So that, managers are more agile than supervisors and administrative personnel are lower than supervisors viewpoint agility. Sumukadas and Sawhney (2004) demonstrated in their research that personnel partnership in organization affairs and their information about internal and external problems of organization increase the agility. Via the partnership of workforce in top level of organization is more and they have a better knowledge about the organization and its external environment, so they understand the necessity of organization Compatibility and organizational changes better than the others, and they try more to achieve the goals of programs. The results of this study adapt with the discussions in Sumukadas and Sawhney research.

In this study, the relationship between the job record and workforce agility is rejected and this result is different with the results found in Kathuria and Partovi (1999) study, which confirm the relation between job record and flexibility and corporation of workforce. Management Inconstancy is a possible reason for this difference. So that, in this research near $50 \%$ of respondents have worked less than 7 years and the average and standard deviation of managers job records is 8 and 6.5. The short term and medium term changes in top manager level lead the people with low job record to work in high and intermediate level of firms and influence the research results. Another justification for this result can be the type of firms and policies and their different criteria about personnel promotion and determining organizational post.

The results of this study have revealed the positive impact of self- Self-awareness on workforce agility. It shows that the awareness of emotions, goals, strengths and weaknesses and logic and honesty of self conscious persons enable them to response reasonable to organizations' wants and needs and have more motivate and ability in represent behaviors and activities proportional with agile organization atmosphere.

According to study results, more ability in self-control leads to more workforce agility. This result is compatible with abilities of self-control people. Regulating the negative and factious emotions, getting along with changeable situations, overcoming the barriers, making decisions and negative judgments, overcoming the ambiguities and reliability, innovation in use of opportunities, optimism and perception of organizational events philosophies are some abilities of self-control people, which can help the agility of person.

The study has revealed that self-motivation has a positive impact on workforce agility. It is argued that efficiency, effective performance, high self-confidence, optimism and high motivation for achieving the goals and standards of self-motivated persons, make them more agile in organization.

This study has proved the positive impact of intrapersonal competence (empathy and social skill) on workforce agility. Intrapersonal competences determine the ability of people in relation management and appropriate interaction with others. Amenability of sympathetic people and respect to others emotions, attitudes and opinions and perception of their needs and wants, justify the sympathetic people's agility. In addition, the ability of widespread relations, solving the disagreements and incompatibility, act in changeable environment, innovation, management in new methods and corporation in work groups make the people with social skills more agile.

Changes and ambiguity in environment cause stress. Stress and anxiety have the most negative impact on the operation and behavior of workforce. The ability of emotion recognition and management help individuals overcomes their stress and anxiety (Vakola and et al., 2003). Salovey and partners (2000) have introduced the recognition of emotions and their management as the fundamental ability of emotional intelligence, which can determine the emotional ability. According to Goleman opinion, recognizing and managing the emotions is the base of emotional intelligence and this competence is the most helpful thing for a person in social life. According 
to Kunnanatt opinion (2008), interpersonal competences are more important than intrapersonal factors and it has more important role in the effects of emotional intelligence on social life. The results of this study are compatible with these discussions and they show that the competence of self-consciousness, self-control and self-motivation have more effect on workforce agility than competence of empathy and social skills.

Practical application of these results in employment and personnel training can help organization agility at individual level a lot and provide the field to establish an agile manufacture system in organizations. Use of emotional intelligence criteria in personnel selecting and recruiting not only can predict right performance and individuals' competence, but also help the organization select right persons. In order to measure emotional intelligence of volunteers, interviews should be done in addition to use of quantitative scales. Using interviews in assessment of emotional intelligence can increase the chance of success in recruiting personnel with high emotional ability (Blank, 2008).

Therefore, the emotional intelligence is an inherent ability and the genes have important role in its creation, but emotional intelligence can grow by training and it needs many efforts and practices (Goleman, 2000). There is no standard method for teaching emotional intelligence in the world but one useful method has been accepted that individuals improve their emotional intelligence by passing six stages including emotional mapping, emotional recognition, emotional acknowledgment, emotional guidance, making empathy and social effects. If the individuals pass these stages, successfully their emotional intelligence structure changes in a noticeable way and their interpersonal and intrapersonal competence of emotional intelligence improves. Using this method is also useful for organizations and helps them to improve their employee's emotional capabilities (Kunnanatt, 2008). In addition to this issue, controlling stress and sadness, controlling depression, anxiety management, anger management, problem solving skills and assertiveness can help organizations improve and increase their employee's emotional capabilities (Carr, 2004; Vakola and et al., 2003).

We faced some limitations during conducting this research. If this research was being done in companies with higher changes like computer accessories production companies, the results have had a high level of credit. Unfortunately, we did not have access to such companies. In addition, we did not have access to any information about prior behaviors and performances of the individuals who had confronted the changes and the plans of their own company. Having these kind of information, could have helped us determine agile individuals. Since in this research the data were collected by a single survey at a single point in time, the results may be influenced by common method bias.

\section{References}

Adeyemo, D. A. (2007). Emotional Intelligence and the Relationship between Job Satisfaction and Organizational Commitment of Employee in Public Parastatals in Oyo State, Nigeria. Pakistan Journal of Social Sciences, 4(1), 324-330.

Ashrafi, N., Xu, P., \& Mathiyalakan, S. (2005). A framework for implementing business agility through knowledge management systems, In Seventh IEEE International Conference on E-Commerce Technology Workshops (CECW'05), Munich, Germany, July 19, 2005.

Bar-On, R. (1997). Bar-On Emotional Quotient Inventory (EQ-i): Technical Manual, Multi-Health Systems, Toronto.

Bar-On, R., Brown, J. M., Kirkcaldy, B. D., \& Thome, E. P. (2000). Emotional expression and implications for occupational stress; an application of the emotional quotient inventory (EQ-i). Personality and Individual Differences, 28, 1107-18. http://dx.doi.org/10.1016/S0191-8869(99)00160-9

Blank, I. (2008). Selecting Employees Based on Emotional Intelligence Competencies: Reap the Rewards and Minimize the Risk. Employee Relations Law Journal, 34(3), 77-85.

Breu, K., Hemingway, S. J., Strathern, M., \& Bridger, D. (2002). Workforce agility: the new employee strategy for the knowledge economy. Journal of Information Technology, 17(1), 21-31. http://dx.doi.org/10.1080/02683960110132070

Carmeli, A. (2002). A conceptual and practical framework of measuring performance of local authorities in financial terms: analyzing the case of Israel. Local Government Studies, 28(1), 21-36. http://dx.doi.org/10.1080/714004135

Carmeli, A. (2003). The Relationship between Emotional Intelligence and Work Attitudes, Behaviour and Outcomes: An Examination Among Senior Managers. Journal of Managerial Psychology, 18(8), 788-813. http://dx.doi.org/10.1108/02683940310511881 
Carmeli, A., Halevy, M. Y., \& Weisberg, J. (2007). The relationship between emotional intelligence and psychological wellbeing. Journal of Managerial Psychology, 24(1), 66-78. http://dx.doi.org/10.1108/02683940910922546

Carmeli, A., \& Josman, Z. E. (2002). The Relationship among Emotional Intelligence, Task Performance and Organizational Citizenship Behaviors. Human performance, 19(4), 403-419. http://dx.doi.org/10.1207/s15327043hup1904_5

Carr, A. (2004). Positive psychology. New York, Brunner-Rout ledge.

Crocitto, M., \& Youssef, M. (2003). The human side of organizational agility. Industrial Management \& Data system, 103(6), 388-897. http://dx.doi.org/10.1108/02635570310479963

Cordery, J., Sevastos, P., Mueller, W., \& Parker, S. (1993). Correlates of employee attitudes toward functional flexibility. Human Relations, 46, 705-23. http://dx.doi.org/10.1177/001872679304600602

Cordery, J., Bartol, K. M., Mueller, W., \& Parker, S. (1991). Mutli skilling: the views of public sector human resource managers. Asia Pacific HRM, 29, 79-89.

Dove, R. (1999). Knowledge management, responsibility, and the agile enterprise. Journal of Knowledge Management, 3(1), 18-35. http://dx.doi.org/10.1108/13673279910259367

Dove, R. (2001). Response Ability: The Language, Structure and Culture of the agile enterprise. Wiley, New York.

Dulewicz, V., \& Higgs, M. (1998). Emotional intelligence: can it be measured reliably and validly using competency data? Competency, 6(1), 1-15.

Dulewicz, V., \& Higgs, M. (2004). Can Emotional Intelligence be developed? International Journal of Human Resource Management, 15(1), 95-111. http://dx.doi.org/10.1080/0958519032000157366

Dyer, L., \& Shafer, R. (2003). Dynamic organizations: achieving marketplace and organizational agility with people. In Peterson, R.S., \& Mannix, E.A. (Eds.), Leading and Managing People in the Dynamic Organization. Laurence Erlbaum Associates, Mahwah, NJ.

Fatt, T. J. P., \& Howe, I. C. K. (2003). Emotional Intelligence of Foreign and Local University Students in Singapore: Implications for Managers. Journal of Business and Psychology, 17, 345-67. http://dx.doi.org/10.1023/A:1022812308150

Fiol, C. M., \& O'Connor, E. J. (2002). When hot and cold collide in radical change processes: lessons from community development. Organization Science, 13, 532-47. http://dx.doi.org/10.1287/orsc.13.5.532.7812

Forsythe, S. (1997). Human factors in agile manufacturing: a brief overview with emphasis on communication and information infrastructure. Human Factors and Ergonomics in Manufacturing, 7(1), 3-10. http://dx.doi.org/10.1002/(SICI)1520-6564(199724)7:1<3::AID-HFM1>3.0.CO;2-7

Fryer, J. S. (1974). Labor flexibility in multiechelon dual-constraint job shops. Management Science, 20(7), 1073- 1080. http://dx.doi.org/10.1287/mnsc.20.7.1073

Frese, M., Fay, D., Hilburger, T., Leng, K., \& Tag, A. (1997). The concept of personal initiative: Operationalization, reliability and validity in two German samples. Journal of Occupational and Organizational Psychology, 70, 139-161. http://dx.doi.org/10.1111/j.2044-8325.1997.tb00639.x

Gardner, H. (1983). Frames of Mind: The Theory of Multiple Intelligences. Basic Books, and New York, NY.

Gabel, R. S., Dolan, S. L., \& Cerdin, J. L. (2005). Emotional intelligence as predictor of cultural adjustment for success in global assignments. Career Development International, 10(5), 375-395. http://dx.doi.org/10.1108/13620430510615300

Ganguly, A., Nilchiani, R., \& Farr, J. V. (2009). Evaluating agility in corporate enterprises. International journal production Economics, 118, 410-423. http://dx.doi.org/10.1016/j.ijpe.2008.12.009

George, J. M., \& Jones, G. R. (2001). Towards a process model of individual change in organizations. Human Relations, 54, 419-44. http://dx.doi.org/10.1177/0018726701544002

Gilad, B. (1996). Business Blindspots, second edition. Tetbury: Infonortics.

Goleman, D. (1995). Emotional intelligence. New York: Bantam Books.

Goleman, D. (1998 a). Working with emotional intelligence. New York: Bantam Books.

Goleman, D. (1998 $)$. Working with emotional intelligence. New York: Bantam Books. 
Goleman, D. (2000). Leadership that gets Results. Harvard Business Review, 78(2).

Goleman, D. (2001). An EI-based theory of performance. In C. Cherniss \& D. Goleman (Eds.), the emotionally intelligent workplace. How to select for, measure, and improve emotional intelligence in individuals, groups, and organizations, San Francisco: Jossey-Bass.

Goleman, D., Boyatzis, R., \& McKee, A. (2002). The new leaders: Transforming the art of leadership into the science of results. Time Warner Paperbacks.

Goldman, S. L., Nagel, R. N., \& Preiss, K. (1995). Agile Competitors and Virtual Organizations: Strategies for Enriching the Customer. Van Nostrand Reinhold, New York.

Griffin, B., \& Hesketh, B. (2003). Adaptable behaviors for successful work and career adjustment. Australian Journal of Psychology, 55(2), 65-73. http://dx.doi.org/10.1080/00049530412331312914

Gunasekaran, A. (1999). Agile manufacturing: a framework for research and development. International Journal of Production Economics, 62, 87-105. http://dx.doi.org/10.1016/S0925-5273(98)00222-9

Hallgren, M. (2009). Lean and agile manufacturing: external and internal drivers and performance outcomes. International Journal of Operations \& Production Management, 29(10), 976-999. http://dx.doi.org/10.1108/01443570910993456

Holstein, W. K., \& Berry, W. L. (1972). The labor assignment decision: an application of work flow structure information. Management Science, 18(7), 390-400. http://dx.doi.org/10.1287/mnsc. 18.7 .390

Hopp, W. J., \& Van Oyen, M. P. (2004). Agile workforce evaluation: a framework for cross-training and coordination. IIE Transactions, 36(10), 919-940. http://dx.doi.org/10.1080/07408170490487759

Huy, Q. N. (1999). Emotional capability, emotional intelligence, and radical change. Academy of Management Review, 24, 325-45.

Insead, Q. N. (1999). Emotional capability, emotional intelligence and radical change. Academy of Management Review, 24(2), 325-345.

Iverson, R. D. (1996). Employee acceptance of organizational change: the role of organizational commitment. The International Journal of Human Resource Management, 7, 122-49. http://dx.doi.org/10.1080/09585199600000121

Jackson, M., \& Johansson, C. (2003). Agility analysis from a production system perspective. Integrated Manufacturing Systems, 14(6), 482-488. http://dx.doi.org/10.1108/09576060310491342

Jordan, P. J., Ashkanasy, N. M., \& Hartel, C. E. J. (2002). Emotional intelligence as a moderator of emotional and behavioral reactions to job insecurity. Academy of Management Review, 27, 361-372.

Kathuria, R., \& Partovi, F. Y. (1999). Work force management practices for manufacturing flexibility. Journal of Operations Management, 18, 21-39. http://dx.doi.org/10.1016/S0272-6963(99)00011-X

Klem, C., \& Schlechter A. F. (2008). The relationship between leader emotional intelligence and psychological climate: An exploratory study. Journal of business management, 39(2), 9-23.

Korkmaz, T., \& Arpac1, E. (2009). Relationship of organizational citizenship behavior with emotional intelligence. Procedia Social and Behavioral Sciences, 1, 2432-2435. http://dx.doi.org/10.1016/j.sbspro.2009.01.428

Kumar Singh, D. S. (2004). Role of Emotional Intelligence in Organizational Learning: An Empirical Study. Singapore management review, 29(2), 55-74.

Kunnanatt, J. T. (2008). Emotional intelligence: theory and description A competency model for interpersonal $\begin{array}{lllll}\text { effectiveness. } & \text { Career Development }\end{array}$ http://dx.doi.org/10.1108/13620430810911083

Luthans, F. (2002). Positive organizational behavior: developing and managing psychological strengths. Academy of Management Executive, 16, 57-65. http://dx.doi.org/10.5465/AME.2002.6640181

Lyusin, D. B. (2006). Emotional Intelligence as a Mixed Construct. Journal of Russian and East European Psychology, 44(6), 54-68. http://dx.doi.org/10.2753/RPO1061-0405440604

Mayer, J. D., Caruso, D., \& Salovey, P. (2000). Emotional Intelligence Meets Traditional Standards for Intelligence. Intelligence, 27, 267-98. http://dx.doi.org/10.1016/S0160-2896(99)00016-1

Mayer, J. D., \& Geher, G. (1996). Emotional intelligence and the identification of emotion. Intelligence, 22, 
89-113. http://dx.doi.org/10.1016/S0160-2896(96)90011-2

Mandell, B., \& pherwani, S. (2003). Relationship between emotional intelligence and transformational leadership style: a gender comparison. Journal of business and psychology, 17(3), 387- 404. http://dx.doi.org/10.1023/A:1022816409059

Meredith, S., \& Francis, D. (2000). Journey towards agility: the agile wheel explored. TQM Magazine, 12(2), 137-143. http://dx.doi.org/10.1108/09544780010318398

Menor, L. J., Roth, A. V., \& Mason, C. H. (2001). Agility in retail banking: a numerical taxonomy of strategic service groups. Manufacturing and Service Operations Management, 3(4), $272-292$.

Mossholder, K., Seton, R., Armenakis, A., \& Harris, S. (2000). Emotion during organizational transformations. Group \& Organization Management, 25, 220-243. http://dx.doi.org/10.1177/1059601100253002

Moon, T. (2010). Emotional intelligence correlates of the four-factor model of cultural intelligence. Journal of Managerial Psychology, 25(8), 876-898. http://dx.doi.org/10.1108/02683941011089134

Musteen, M., Barker, V. L., \& Baeten, V. L. (2006). CEO attributes associated with attitude toward change: The direct and moderating effects of CEO tenure. Journal of Business Research, 59, $604-612$. http://dx.doi.org/10.1016/j.jbusres.2005.10.008

Myers, L. L., \& Tucker L. M. (2005). Increasing awareness of emotional intelligence in business curriculum. Business Communication Quarterly, 68(1), 44-51. http://dx.doi.org/10.1177/1080569904273753

Nikolaou, I., \& Tsaousis, I. (2005). Emotional intelligence in the workplace: exploring its effects on occupational stress and organizational commitment. International Journal of Organizational Analysis, 10(4), 327-343. http://dx.doi.org/10.1108/eb028956

Oyen, M. P., Esma G. S., Hopp, W. J. (2001). Performance opportunity for workforce agility in collaborative and $\begin{array}{llllll}\text { noncollaborative } & \text { work } & \text { systems. } & \text { IIE } & \text { Transactions, } & 33,\end{array}$ http://dx.doi.org/10.1080/07408170108936871

Palmer, B., Walls, M., Burgess, Z., \& Stough, C. (2002). Emotional Intelligence and Effective Leadership. Leadership and Organizational Development Journal, 22(1), 5-10. http://dx.doi.org/10.1108/01437730110380174

Petrides, K. V., \& Furnham, A. (2000). Gender Differences in Measured and Self-Estimated Trait Emotional Intelligence. Sex Roles, 42(5), 449-461. http://dx.doi.org/10.1023/A:1007006523133

Pinker, E. L, Hsiao-Hui, \& Berman, O. (2010). Can flexibility be constraining. IIE Transactions, 42(1), 45- 59. http://dx.doi.org/10.1080/07408170903113789

Plonka, F. S. (1997). Developing a lean and agile workforce. Human Factors and Ergonomics in Manufacturing, 7(1), 11-20. http://dx.doi.org/10.1002/(SICI)1520-6564(199724)7:1<11::AID-HFM2>3.0.CO;2-J

Prahalad, C. K., \& Hamel, G. (1990). The core competence of the corporation. Harvard Business Review, 68 (3), 79-91.

Pulakos, E. D., Schmitt, N., Dorsey, D. W., Arad, S., Hedge, J. W., \& Borman, W. C. (2001). Predicting Adaptive Performance: Further Tests of a Model of Adaptability. Human performance, 15(4), 299-323. http://dx.doi.org/10.1207/S15327043HUP1504_01

Salovey, P., \& Mayer, J. D. (1990). Emotional intelligence. Imagination, Cognition, and Personality, 9, 185-211.

Sharifi, H., Colquhoun, G., Barclay, I., \& Dann, Z. (2001). Agile manufacturing: a management and operational framework. Proceedings of the Institution of Mechanical Engineers, Part B. Journal of Engineering Manufacture, 215(6), 857-869. http://dx.doi.org/10.1243/0954405011518647

Sharifi, H., \& Zhang, Z. (1999). A methodology for achieving agility in manufacturing organizations: an introduction. International Journal of Production Economics, 62(1), 7-22. http://dx.doi.org/10.1016/S0925-5273(98)00217-5

Sherehiy, B., Karwowski, W., \& Layer, J. K. (2007). A review of enterprise agility: Concepts, frameworks, and attributes. International Journal of Industrial Ergonomics, 37, 445-460. http://dx.doi.org/10.1016/j.ergon.2007.01.007

Slaski, M., \& Cartwright, S. (2003). Developmental emotional intelligence training: implications for stress. Health and performance. Stress and Health, 19, 233-239. http://dx.doi.org/10.1002/smi.979 
Suliman, A. M., \& Al-Shaikh, Fuad N. (2007). Emotional intelligence at work: links to conflict and innovation. Employee Relations, 29(2), 208-220. http://dx.doi.org/10.1108/01425450710720020

Sumukadas, N., \& Sawhney, R. (2004). Workforce agility through employee involvement. IIE Transactions, 36(10), 1011-1021. http://dx.doi.org/10.1080/07408170490500997

Sunindijo Riza Yosia, Hadikusumo Bonaventura H. W., \& Ogunlana S. (2007). Emotional Intelligence and Leadership Styles in Construction Project Management. Journal of management in engineering, 23(4), 166-170. http://dx.doi.org/10.1061/(ASCE)0742-597X(2007)23:4(166)

Thilam, L., \& Kirby, S. L. (2002). Is Emotional Intelligence an Advantage? An Exploration of the Impact of Emotional and General Intelligence on Individual Performance. The Journal of Social Psychology, 142(1), 133-143. http://dx.doi.org/10.1080/00224540209603891

Vakola, M., Tsaousis, I., \& Nikolaou, I. (2004). The role of emotional intelligence and personality variables on attitudes toward organizational change. Journal of managerial psychology, 19(2), 88-110. http://dx.doi.org/10.1108/02683940410526082

Vinodh, S., Sundararaj, G., \& Devadasan, S. R. (2008). Total agile design system model via literature exploration. Industrial Management \& Data Systems, 109(4), 570-588. http://dx.doi.org/10.1108/02635570910948678

Vinodh, S., Sundararaj, G., Devadasan, S. R., Kuttalingam, D., \& Rajanayagam, (2009). Achieving agility in manufacturing through finite element mould analysis. Journal of Manufacturing Technology Management, 21(5), 604-623. http://dx.doi.org/10.1108/17410381011046995

Weisinger, H. (1998). Emotional intelligence at work. San Francisco: Jossey-Bass.

Wong, C. S., \& Law, K. S. (2002). The effects of leader and follower emotional intelligence on performance and attitude: An exploratory study. The Leadership Quarterly, 13, 243-274. http://dx.doi.org/10.1016/S1048-9843(02)00099-1

Yost, C. A., \& Tucker, M. L. (2000). Are effective teams more emotionally intelligent? Confirming the importance of effective communication in teams. Delta Pi Epsilon, 42(2), 101-109.

Yost, C. A., Tucker, M. L., \& Barone, F. (2001). Testing the structure of the Weisinger emotional intelligence instrument. Unpublished manuscript, The Ohio University at Athens.

Yusuf, Y., Sarhadi, M., \& Gunasekaran, A. (1999). Agile manufacturing: the drivers, concepts and attributes. International Journal of Production Economics, 62(1-2), 33-43. http://dx.doi.org/10.1016/S0925-5273(98)00219-9

Zhang, Z. D. (2010). Towards theory building in agile manufacturing strategies-Case studies of an agility taxonomy. International journal production Economics, 131, 303-312. http://dx.doi.org/10.1016/j.ijpe.2010.08.010 